\title{
Efek Antidiare Infusa Daun Senggani (Melastoma malabathricum L.) Pada Mencit Jantan Galur Swiss Webster Yang Di Induksi Oleum ricini
}

\author{
(Antidiarrheal Effect of Senggani Leaves Infusion \\ (Melastoma malabathricum L.) in Swiss Webster Male Mice \\ Induced by Oleum ricini)
}

\author{
NOVA SULISKA ${ }^{1 *}$, THITO DWI EVRIANTO ${ }^{2}$, HERLINDA $^{2}$ \\ 1) Kelompok Keahlian Farmakologi-Farmasi Klinik, Sekolah Farmasi, Institut Teknologi \\ Bandung \\ 2) Program Studi Farmasi, Fakultas MIPA, Universitas Al Ghifari
}

Diterima 11 Juni 2019, Disetujui 13 September 2019

\begin{abstract}
Abstrak: Diare merupakan gangguan buang air besar (BAB) yang ditandai dengan BAB lebih dari 3 kali sehari dengan konsistensi tinja cair, dapat disertai dengan darah dan atau lendir. Salah satu tanaman yang berkhasiat dan digunakan masyarakat sebagai antidiare adalah senggani (Melastoma malabathricum L.). Penelitian ini bertujuan untuk mengetahui efek dan dosis efektif infusa daun senggani terhadap mencit yang diinduksi diare dengan Oleum ricini. Mencit dikelompokkan menjadi 5 kelompok: kelompok kontrol positif (induksi diare), kelompok pembanding (loperamid), dan kelompok uji infusa daun senggani dosis $26 \mathrm{mg} / \mathrm{kg} \mathrm{BB}, 52 \mathrm{mg} / \mathrm{kg} \mathrm{BB}$, dan $104 \mathrm{mg} / \mathrm{kg}$ BB. Mencit diinduksi diare dengan Oleum ricini, 30 menit kemudian mencit diberikan sediaan uji kecuali kelompok kontrol positif. Frekuensi, bobot, dan konsistensi feses diukur setiap 30 menit selama 4 jam. Hasil penelitian menunjukkan kelompok infusa daun senggani dosis $52 \mathrm{mg} / \mathrm{kg}$ BB menunjukkan frekuensi dan bobot feses yang lebih rendah berbeda bermakna dibandingkan dengan kelompok kontrol positif $(\mathrm{P}<0,5)$ pada pengamatan menit ke-240. Konsistensi feses kelompok infusa daun senggani dosis $52 \mathrm{mg} / \mathrm{kg}$ $\mathrm{BB}$ cenderung normal pada pengamatan menit ke-240. Infusa daun senggani dosis $52 \mathrm{mg} / \mathrm{kg} \mathrm{BB}$ menunjukkan efek antidiare yang paling baik dibandingkan dengan infusa daun senggani dosis $26 \mathrm{mg} /$ $\mathrm{kg}$ BB dan $104 \mathrm{mg} / \mathrm{kg}$ BB pada mencit yang diinduksi Oleum ricini.
\end{abstract}

Kata Kunci: daun senggani, diare, Oleum ricini, Melastoma malabathricum L.

\begin{abstract}
Diarrhea is a disorder of defecation more than 3 times a day with the consistency of liquid stool, blood and/or mucus. The plants that is used by the community for diarrhea is senggani (Melastoma malabathricum L.). This study aims to determine the antidiarrheal effects and dose of senggani leaves infusion in mice induced by Oleum ricini. Mice were grouped into 5 groups: the positive control group (diarrhea induction), the comparison group (loperamide), and senggani leaves infusion test group with a dose of $26 \mathrm{mg} / \mathrm{kg}$ bw, $52 \mathrm{mg} / \mathrm{kg}$ bw, and $104 \mathrm{mg} / \mathrm{kg}$ bw. Mice induced diarrhea with Oleum ricini, 30 minutes later the mice were given the samples, except the positive control group. The faecal frequency, weight, and consistency were measured every 30 minutes for 4 hours. Senggani leaves infusion group $52 \mathrm{mg} / \mathrm{kg}$ bw showed the frequency and faecal weight were significantly different compared to the positive control group $(\mathrm{P}<0.5)$ at 240 minutes observation. The faecal consistency of senggani leaves infusion groups $52 \mathrm{mg} / \mathrm{kg}$ bw tends to be normal at 240 minutes observation. Senggani leaves infusion $52 \mathrm{mg} / \mathrm{kg}$ bw showed the best antidiarrheal effect compared to senggani leaf infusion $26 \mathrm{mg} / \mathrm{kg}$ bw and $104 \mathrm{mg} / \mathrm{kg}$ bw in Oleum ricini-induced mice.
\end{abstract}

Keywords: senggani leaves, diarrhea, Oleum ricini, Melastoma malabathricum L.

*Penulis korespondensi: Hp. 082317651596

email: novasuliska@fa.itb.ac.id 


\section{PENDAHULUAN}

DIARE merupakan gangguan buang air besar (BAB) yang ditandai dengan $\mathrm{BAB}$ lebih dari 3 kali sehari dengan konsistensi tinja cair, dapat disertai dengan darah dan atau lendir (Kemenkes, 2013). Insidensi diare pada balita semakin meningkat setiap tahun, berdasarkan data hasil riset kesehatan dasar tahun 2018, insidensi diare pada balita di Indonesia meningkat menjadi $15,2 \%$ sebelumnya $6,7 \%$ pada tahun 2013 dan insidensi tertinggi terjadi di provinsi Aceh (10,2\%). Karakteristik diare balita tertinggi terjadi pada kelompok umur $12-23$ bulan $(7,6 \%)$, laki-laki $(5,5 \%)$, tinggal di daerah pedesaan $(5,3 \%)$, dan kelompok kuintil indeks kepemilikan terbawah $(6,2 \%)^{(1,2)}$.

Berdasarkan penyebabnya diare diklasifikasikan menjadi diare spesifik dan non spesifik. Diare spesifik dapat disebabkan oleh infeksi patogen seperti virus, bakteri, dan parasit. Beberapa bakteri yang dapat menyebabkan diare yaitu Staphylococcus aureus, Bacillus cereus, Clostridium perferingens, Escherichia coli, Vibrio cholerae, Shigella sp, Salmonella sp, Clostridium difficile, Campylobacter jejuni, Yersinia enterolitica, Klebsiella pneumoniae, Vibrio haemolyticus ${ }^{(3)}$.

Sebagian besar obat antidiare sintetik dapat menimbulkan efek samping yang tidak diinginkan, sehingga diharapkan dapat diperolehnya obat alternatif dari bahan alam yang lebih aman. Salah satu tanaman yang berkhasiat dan digunakan masyarakat sebagai antidiare adalah senggani (Melastoma malabathricum L.). Secara tradisional, daun senggani digunakan masyarakat Indonesia untuk mengobati demam (antipiretik), penghilang rasa nyeri (analgetik), peluruh kencing (diuretik), melancarkan aliran darah, menghilangkan bengkak (anti-inflamasi), bisul, diare, haid tidak lancar, hepatitis, sariawan, ASI tidak lancar, keracunan singkong dan radang pada dinding pembuluh darah ${ }^{(4)}$. Daun senggani digunakan oleh masyarakat suku Karen Thailand sebagai obat untuk diare, disentri, dan sariawan ${ }^{(5)}$. Daun senggani juga digunakan oleh masyarakat Batak Toba sebagai obat tradisional untuk mengobati luka dan nyeri pada perut $^{(6)}$.

Secara umum, bagian tanaman senggani seperti daun, akar dan kulit digunakan oleh masyarakat Malaysia, India, dan Indonesia sebagai obat tradisional untuk penyakit diare, disentri, hemoroid, luka, sakit perut, kembung, dan sariawan ${ }^{(7)}$. Berdasarkan latar belakang diatas, maka dilakukan penelitian untuk mengetahui efek dan dosis yang paling efektif dari infusa daun senggani dalam mengatasi diare.

\section{BAHAN DAN METODE}

Bahan. Daun senggani (Melastoma malabathricum L.), loperamid $\mathrm{HCl}$, aquadest, $\mathrm{CMC} \mathrm{Na}$, Oleum ricini, gelatin 1\%, amil alkohol, asam klorida $2 \mathrm{~N}$. Hewan uji (mencit jantan Swiss webster dengan berat badan 20-30 g sebanyak 25 ekor) diperoleh dari Sekolah Ilmu dan Teknologi Hayati Institut Teknologi Bandung.

Alat

Gunting, beaker glass, batang pengaduk, sonde oral, kertas saring, gelas ukur, labu ukur, tabung reaksi, mortir dan stamper, penangas air, alat timbang analitik, toples, bejana kaca, spatel, stopwatch, termometer. .

Metode

Sebanyak 25 ekor mencit jantan Swiss webster dibagi menjadi 5 kelompok secara acak, diaklimatisasi selama 7 hari dan diberi makan pakan standar laboratorium serta minum ad libitum.

Kelompok uji terdiri dari :

1. Kelompok 1: Kelompok kontrol positif (suspensi CMC Na 1\%)

2. Kelompok 2: Kelompok pembanding (suspensi loperamid dosis $2 \mathrm{mg} / \mathrm{kg} \mathrm{BB}$ )

3. Kelompok 3: Kelompok Dosis 1 (infusa daun senggani dosis $26 \mathrm{mg} / \mathrm{kg} \mathrm{BB})$

4. Kelompok 4: Kelompok Dosis 2 (infusa daun senggani dosis $52 \mathrm{mg} / \mathrm{kg} \mathrm{BB}$ )

5. Kelompok 5: Kelompok Dosis 3 (infusa daun senggani dosis $104 \mathrm{mg} / \mathrm{kg} \mathrm{BB}$ )

Mencit dipuasakan terlebih dahulu selama kurang lebih 2 jam sebelum percobaan, tetapi air minum tetap diberikan. Selanjutnya, mencit diinduksi diare dengan pemberian $0,5 \mathrm{ml}$ Oleum ricini secara oral. 30 menit setelah induksi, masing-masing mencit diberikan sediaan uji sesuai kelompok yang sudah ditentukan. Setiap mencit di tempatkan terpisah dan tempat dari masing-masing mencit di lapisi dengan kertas saring. Proses pengamatan dilakukan setiap 30 menit selama 4 jam, meliputi frekuensi diare, bobot feses dan konsistensi feses. Data dianalisis dengan metode statistik uji $t$ student.

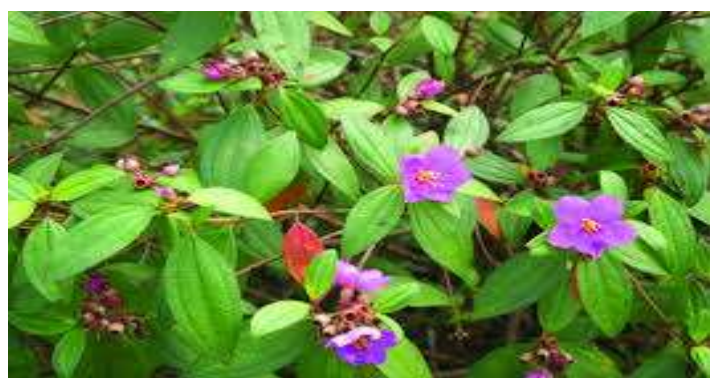

Gambar 1. Daun Senggani ${ }^{(8)}$ 


\section{HASIL DAN PEMBAHASAN}

Hasil determinasi yang dilakukan di Laboratorium Taksonomi Tumbuhan, Departemen Biologi Fakultas Matematika dan Ilmu Pengetahuan Alam Universitas Padjadjaran Bandung menunjukkan bahwa tanaman yang digunakan pada penelitian ini adalah benar tanaman senggani (Melastoma malabathricum L.). Hasil uji fitokimia menunjukkan daun segar dan infusa daun senggani mengandung saponin, tannin, dan flavonoid yang ditunjukkan pada Tabel 1. Hal ini sesuai dengan pengujian yang dilakukan oleh Zakaria dkk. yang melaporkan hasil skrining fitokimia daun senggani mengandung flavonoid, triterpen, tannin, saponin, dan steroid ${ }^{(9)}$.

Oleum ricini digunakan sebagai penginduksi diare. Oleum ricini di usus halus akan dihidrolisis oleh lipase menjadi gliserol dan zat aktifnya yakni asam risinoleat, yang terutama bekerja di usus halus untuk menstimulasi sekresi cairan dan elektrolit serta menstimulasi peristaltik usus ${ }^{(10)}$.

Sediaan infusa daun senggani dipilih karena cara pembuatannya sederhana yaitu mencampurkan simplisia dengan air secukupnya dan dipanaskan pada suhu 900. Metode ini lebih mudah diikuti masyarakat

Tabel 1. Hasil skrining fitokimia daun senggani (Melastoma malabathricum L.).

\begin{tabular}{ccc}
\hline Golongan & Daun segar & Infusa \\
senyawa & + & + \\
Saponin & + & + \\
Tanin & + & + \\
Flavonoid & + \\
\hline
\end{tabular}

Keterangan:

$+=$ terdapat senyawa yang di uji

- = tidak terdapat senyawa yang di uji dan tidak membutuhkan peralatan khusus. Penyarian dengan cara ini menghasilkan sediaan yang tidak stabil dan mudah tercemar oleh mikroorganisme, sehingga sediaan tidak boleh disimpan lebih dari 24 jam ${ }^{(11)}$.

Parameter pertama yang diamati pada pengujian ini adalah jumlah total diare sampai pengamatan menit ke 240 yang dapat dilihat pada Tabel 2. Hasil penelitian menunjukkan bahwa kelompok kontrol positif mengalami frekuensi diare yang paling banyak pada setiap pengamatan 30 menit dan sampai akhir pengamatan. Hal ini menunjukkan bahwa induksi diare menggunakan Oleum ricini berhasil.

Kelompok uji infusa daun senggani dosis $52 \mathrm{mg} /$ $\mathrm{kg}$ BB menunjukkan jumlah total diare yang paling sedikit dibandingkan dengan kelompok uji infusa daun senggani dosis $26 \mathrm{mg} / \mathrm{kg} \mathrm{BB}$ dan dosis $104 \mathrm{mg} / \mathrm{kg} \mathrm{BB}$.

Parameter kedua yang diamati pada pengujian ini adalah frekuensi diare yang dapat dilihat pada Tabel 3. Hasil penelitian menunjukan bahwa pada kelompok uji infusa daun senggani dosis $52 \mathrm{mg} / \mathrm{kg}$ BB terjadi penurunan frekuensi diare dan berbeda bermakna jika dibandingkan dengan kelompok kontrol positif $(\mathrm{P}<0,05)$ pada pengamatan menit ke-240.

Kelompok uji infusa daun senggani pada dosis $26 \mathrm{mg} / \mathrm{kg} \mathrm{BB}$ dan dosis $104 \mathrm{mg} / \mathrm{kg}$ BB menunjukkan penurunan frekuensi diare tetapi tidak berbeda bermakna jika dibandingkan dengan kelompok kontrol positif $(\mathrm{P}<0,05)$ pada pengamatan hingga menit ke240.

Kelompok pembanding (Loperamid $2 \mathrm{mg} / \mathrm{kg} \mathrm{BB}$ ) menunjukkan penurunan frekuensi diare dan berbeda bermakna jika dibandingkan dengan kelompok kontrol positif $(\mathrm{P}<0,05)$ pada pengamatan menit ke-240. Kelompok uji infusa daun senggani dosis $52 \mathrm{mg} / \mathrm{kg}$ BB menunjukkan penurunan frekuensi diare yang

Tabel 2. Data jumlah total diare pada masing-masing kelompok uji

\begin{tabular}{|c|c|c|c|c|c|c|c|c|c|}
\hline \multirow{2}{*}{ Kelompok } & \multicolumn{8}{|c|}{ Frekuensi diare pada menit ke- } & \multirow{2}{*}{$\begin{array}{c}\text { Jumlah } \\
\text { total } \\
\text { diare } \\
\end{array}$} \\
\hline & 30 & 60 & 90 & 120 & 150 & 180 & 210 & 240 & \\
\hline Kontrol positif & 2,00 & 2,20 & 2,00 & 2,20 & 2,00 & 2,40 & 1,60 & 1,80 & 16,20 \\
\hline $\begin{array}{c}\text { Pembanding } \\
\text { (Loperamid } 2 \\
\mathrm{mg} / \mathrm{kg} \mathrm{BB})\end{array}$ & 1,20 & 1,20 & 0,80 & 0,80 & 1,00 & 0,60 & 0,80 & 0,40 & 6,80 \\
\hline $\begin{array}{c}\text { Dosis } 1 \text { (Infusa } \\
\text { daun senggani } 26 \\
\mathrm{mg} / \mathrm{kg} \mathrm{BB} \text { ) }\end{array}$ & 2,00 & 2,00 & 1,60 & 1,60 & 1,60 & 1,40 & 1,40 & 1,40 & 13,00 \\
\hline $\begin{array}{c}\text { Dosis } 2 \text { (Infusa } \\
\text { daun senggani } 52 \\
\mathrm{mg} / \mathrm{kg} \mathrm{BB})\end{array}$ & 1,60 & 1,80 & 1,20 & 1,20 & 1,40 & 1,00 & 0,80 & 0,60 & 9,60 \\
\hline $\begin{array}{c}\text { Dosis } 3 \text { (Infusa } \\
\text { daun senggani } \\
104 \mathrm{mg} / \mathrm{kg} \mathrm{BB} \text { ) }\end{array}$ & 2,20 & 2,40 & 1,80 & 2,00 & 1,80 & 1,80 & 1,80 & 1,60 & 15,40 \\
\hline
\end{tabular}


Tabel 3. Data analisis statistik frekuensi diare pada masing-masing kelompok uji

\begin{tabular}{ccccccccc}
\hline \multirow{2}{*}{ Kelompok } & \multicolumn{7}{c}{ Frekuensi diare pada menit ke- } \\
\cline { 2 - 9 } & $\mathbf{3 0}$ & $\mathbf{6 0}$ & $\mathbf{9 0}$ & $\mathbf{1 2 0}$ & $\mathbf{1 5 0}$ & $\mathbf{1 8 0}$ & $\mathbf{2 1 0}$ & $\mathbf{2 4 0}$ \\
\hline & 2,00 & 2,20 & 2,00 & 2,20 & 2,00 & 2,4 & 1,60 & 1,80 \\
Kontrol positif & \pm & \pm & \pm & \pm & \pm & \pm & \pm & \pm \\
& 1,22 & 1,30 & 1,58 & 1,48 & 1,87 & 1,82 & 0,89 & 0,84 \\
Pembanding & 1,20 & 1,20 & 0,80 & 0,80 & 1,00 & 0,60 & 0,80 & 0,40 \\
(Loperamid 2 & \pm & \pm & \pm & \pm & \pm & \pm & \pm & \pm \\
mg/kg BB) & 0,45 & 0,45 & 0,84 & 0,84 & 1,00 & 0,55 & 0,84 & $0,55^{*}$ \\
Dosis 1 (Infusa & 2,00 & 2,00 & 1,60 & 1,60 & 1,60 & 1,40 & 1,40 & 1,40 \\
daun senggani 26 & \pm & \pm & \pm & \pm & \pm & \pm & \pm & \pm \\
mg/kg BB) & 0,71 & 0,71 & 0,55 & 0,89 & 0,55 & 0,55 & 0,55 & 0,89 \\
Dosis 2 (Infusa & 1,60 & 1,80 & 1,20 & 1,20 & 1,40 & 1,00 & 0,80 & 0,60 \\
daun senggani 52 & \pm & \pm & \pm & \pm & \pm & \pm & \pm & \pm \\
mg/kg BB) & 0,55 & 0,84 & 0,84 & 0,84 & 0,55 & 0,71 & 0,84 & $0,55^{*}$ \\
Dosis 3 (Infusa & 2,20 & 2,40 & 1,80 & 2,00 & 1,80 & 1,80 & 1,80 & 1,60 \\
daun senggani 104 & \pm & \pm & \pm & \pm & \pm & \pm & \pm & \pm \\
mg/kg BB) & 0,84 & 1,14 & 0,45 & 1,00 & 0,45 & 0,84 & 0,84 & 0,89 \\
\hline
\end{tabular}

Keterangan: * berbeda bermakna dibandingkan dengan kelompok kontrol positif $(\mathrm{P}<0,05)$

Tabel 4. Data analisis statistik bobot feses pada masing-masing kelompok uji

\begin{tabular}{|c|c|c|c|c|c|c|c|c|}
\hline \multirow{2}{*}{ Kelompok } & \multicolumn{8}{|c|}{ Bobot feses (g) } \\
\hline & 30 & 60 & 90 & 120 & 150 & 180 & 210 & 240 \\
\hline \multirow{2}{*}{ Kontrol positif } & 0,20 & 0,20 & 0,20 & 0,22 & 0,20 & 0,24 & 0,16 & 0,18 \\
\hline & 0,12 & 0,12 & 0,16 & 0,15 & 0,19 & 0,18 & 0,09 & 008 \\
\hline Pembanding & 0,12 & 0,12 & 0,08 & 0,08 & 0,10 & 0,06 & 0,08 & 0,04 \\
\hline (Loperamid 2 & \pm & \pm & \pm & \pm & \pm & \pm & \pm & \pm \\
\hline Dosis 1 (Infusa & 0,22 & 0,24 & 0,18 & 0,20 & 0,18 & 0,18 & 0,18 & 0,16 \\
\hline daun senggani 26 & \pm & \pm & \pm & \pm & \pm & \pm & \pm & \pm \\
\hline $\mathrm{mg} / \mathrm{kg} \mathrm{BB})$ & 0,08 & 0,11 & 0,04 & 0,10 & 0,04 & 0,08 & 0,08 & 0,09 \\
\hline Dosis 2 (Infusa & 0,16 & 0,18 & 0,12 & 0,12 & 0,14 & 0,10 & 0,08 & $0,06^{*}$ \\
\hline daun senggani 52 & \pm & \pm & \pm & \pm & \pm & \pm & \pm & \pm \\
\hline
\end{tabular}

Keterangan: * berbeda bermakna dibandingkan dengan kelompok kontrol positif $(\mathrm{P}<0,05)$

hampir sama dengan kelompok pembanding pada pengamatan menit ke-240.

Parameter ketiga yang diamati pada pengujian ini adalah bobot feses yang dapat dilihat pada Tabel 4 . Hasil penelitian menunjukan bahwa pada kelompok uji infusa daun senggani dosis $52 \mathrm{mg} / \mathrm{kg}$ bb bobot feses lebih kecil dan berbeda bermakna jika dibandingkan dengan kelompok kontrol positif $(\mathrm{P}<0,05)$ pada pengamatan menit ke-240.

Kelompok uji infusa daun senggani pada dosis $26 \mathrm{mg} / \mathrm{kg}$ BB dan dosis $104 \mathrm{mg} / \mathrm{kg}$ BB menunjukkan bobot feses lebih kecil tetapi tidak berbeda bermakna jika dibandingkan dengan kelompok kontrol positif $(\mathrm{P}<0,05)$ pada pengamatan hingga menit ke-240.

Hasil penelitian menunjukkan pada dosis 104 $\mathrm{mg} / \mathrm{kg}$ BB terjadi penurunan aktivitas antidiare. Pada sediaan infusa daun senggani terdapat beberapa senyawa yang memiliki aktivitas antidiare dan mungkin juga terdapat senyawa lain yang bersifat antagonisnya (menurunkan efek antidiare), semakin tinggi dosis maka senyawa yang bersifat antagonisnya juga semakin banyak hingga dapat menurunkan aktivitas antidiare.

Kelompok pembanding (Loperamid $2 \mathrm{mg} / \mathrm{kg} \mathrm{BB}$ ) menunjukkan penurunan frekuensi diare dan berbeda bermakna jika dibandingkan dengan kelompok kontrol positif $(\mathrm{P}<0,05)$ pada pengamatan menit ke-240. Kelompok uji infusa daun senggani dosis $52 \mathrm{mg} / \mathrm{kg}$ BB menunjukkan penurunan frekuensi diare yang hampir sama dengan kelompok pembanding pada pengamatan menit ke-240.

Kelompok pembanding (loperamid $2 \mathrm{mg} / \mathrm{kg} \mathrm{BB}$ ) menunjukkan bobot feses yang lebih kecil dan berbeda bermakna jika dibandingkan dengan kelompok kontrol 
positif $(\mathrm{P}<0,05)$ pada pengamatan menit ke-240.

Bobot feses kelompok uji infusa daun senggani dosis $52 \mathrm{mg} / \mathrm{kg}$ BB hampir sama dengan kelompok pembanding loperamid. Hal ini menunjukkan bahwa efek antidiare infusa daun senggani dosis $52 \mathrm{mg} / \mathrm{kg}$ BB hampir sama dengan efek antidiare dari loperamid.

Loperamid merupakan obat golongan agonis reseptor opioid yang mekanisme kerjanya mengurangi aktivitas pleksus myenteric usus besar sehingga mengurangi ritme kontraksi usus, menghambat peristaltik dan memperpanjang waktu transit, mempengaruhi perpindahan air dan elektrolit melalui mukosa usus, meningkatkan viskositas dan mencegah kehilangan air dan elektrolit. (12)

Oleum ricini menimbulkan diare dengan cara menstimulasi usus halus, sehingga loperamid $\mathrm{HCl}$ merupakan obat pilihan antidiare untuk diare yang disebabkan oleh Oleum ricini.

Parameter keempat yang diamati pada pengujian ini adalah konsistensi feses yang dapat dilihat pada Tabel 5. Hasil penelitian menunjukkan bahwa pada kelompok kontrol positif terlihat konsistensi feses masih lembek pada pengamatan hingga menit ke-240. Hal ini menunjukkan bahwa pada kelompok kontrol positif, diare masih terjadi sampai menit ke-240.

Pada kelompok uji infusa daun senggani dosis 26 $\mathrm{mg} / \mathrm{kg} \mathrm{BB}$ dan dosis $104 \mathrm{mg} / \mathrm{kg} \mathrm{BB}$, konsistensi feses masih lembek dan berair, sedangkan pada kelompok uji dosis $52 \mathrm{mg} / \mathrm{kg}$ BB konsistensi feses sudah cenderung normal. Hal ini menunjukkan bahwa infusa daun senggani dosis $52 \mathrm{mg} / \mathrm{kg}$ BB menunjukkan efek antidiare yang paling baik dibandingkan dengan infusa daun senggani dosis $26 \mathrm{mg} / \mathrm{kg}$ BB dan $104 \mathrm{mg} / \mathrm{kg} \mathrm{BB}$. Semakin besar dosis, efek antidiare tidak semakin baik, hal ini menunjukkan bahwa peningkatan dosis tidak sebanding dengan efek antidiare.

Dari semua parameter, kelompok uji infusa daun senggani dosis $52 \mathrm{mg} / \mathrm{kg}$ BB menunjukkan efek antidiare paling baik dan hampir mirip dengan efek antidiare kelompok pembanding loperamid.

Hasil penapisan fitokimia dari daun segar dan infusa daun senggani menunjukan adanya golongan

Tabel 5. Data konsistensi feses pada masing-masing kelompok uji

\begin{tabular}{|c|c|c|c|c|c|c|c|c|}
\hline \multirow[t]{2}{*}{ Kelompok } & \multicolumn{8}{|c|}{ Konsistensi feses pada menit ke- } \\
\hline & 30 & 60 & 90 & 120 & 150 & 180 & 210 & 240 \\
\hline \multirow{5}{*}{ Kontrol positif } & + & + & ++ & - & +++ & +++ & ++ & ++ \\
\hline & +++ & +++ & - & ++ & ++ & +++ & ++ & ++ \\
\hline & + & + & +++ & ++ & - & ++ & + & + \\
\hline & + & ++ & ++ & ++ & + & - & + & + \\
\hline & + & + & + & ++ & ++ & + & + & ++ \\
\hline \multirow{5}{*}{$\begin{array}{c}\text { Pembanding } \\
\text { (Loperamid } 2 \\
\text { mg/kg BB) }\end{array}$} & ++ & + & + & - & ++ & - & + & - \\
\hline & + & + & ++ & + & - & + & - & - \\
\hline & + & ++ & + & - & ++ & - & + & + \\
\hline & + & + & - & + & - & + & - & + \\
\hline & + & + & - & ++ & + & + & ++ & - \\
\hline \multirow{5}{*}{$\begin{array}{l}\text { Dosis } 1 \text { (Infusa } \\
\text { daun senggani } \\
26 \mathrm{mg} / \mathrm{kg} \mathrm{BB})\end{array}$} & ++ & +++ & ++ & + & ++ & + & ++ & + \\
\hline & + & + & ++ & ++ & + & + & ++ & ++ \\
\hline & ++ & + & + & + & ++ & ++ & ++ & ++ \\
\hline & ++ & ++ & ++ & ++ & ++ & + & ++ & +++ \\
\hline & + & ++ & + & +++ & ++ & + & ++ & ++ \\
\hline \multirow{5}{*}{$\begin{array}{l}\text { Dosis } 2 \text { (Infusa } \\
\text { daun senggani } \\
52 \mathrm{mg} / \mathrm{kg} \mathrm{BB} \text { ) }\end{array}$} & ++ & +++ & ++ & + & ++ & ++ & ++ & + \\
\hline & + & + & ++ & + & + & + & - & - \\
\hline & ++ & ++ & + & - & ++ & - & + & + \\
\hline & ++ & - & - & ++ & + & + & - & + \\
\hline & + & ++ & + & ++ & + & + & + & - \\
\hline \multirow{5}{*}{$\begin{array}{l}\text { Dosis } 3 \text { (Infusa } \\
\text { daun senggani } \\
104 \mathrm{mg} / \mathrm{kg} \mathrm{BB} \text { ) }\end{array}$} & ++ & +++ & ++ & + & ++ & ++ & +++ & ++ \\
\hline & ++ & +++ & ++ & ++ & ++ & + & + & ++ \\
\hline & ++ & ++ & ++ & +++ & ++ & ++ & + & + \\
\hline & ++ & + & ++ & ++ & ++ & + & ++ & +++ \\
\hline & + & ++ & + & ++ & ++ & +++ & ++ & + \\
\hline
\end{tabular}

Keterangan:

$$
\begin{array}{ll}
+ & =\text { feses normal } \\
++ & =\text { feses lembek } \\
+++ & =\text { feses berair/berlendir }
\end{array}
$$


senyawa saponin, tanin, dan flavonoid.

Tanaman senggani mengandung kaempferol-3-O$\beta$-D-xyloside, quercetin- l 3-O-a-L-rhamnosyl- $(1,2)$ $\beta$-D-galactoside, flavan-3-ol, 4-methylpeonidin-7-O$\beta$-D-glucoside, antosianin dan tannin (7).

Tanin merupakan adstringensia yang mekanismenya menciutkan pori-pori dan selaput lendir usus sehingga mengurangi absorpsi air ke dalam usus dan mengurangi peristaltik usus ${ }^{(13)}$. Golongan senyawa yang diprediksi berperan sebagai antidiare pada infusa daun senggani adalah tanin.

Ekstrak air daun senggani terbukti memiliki aktivitas antidiare dengan menurunkan frekuensi diare dan bobot feses pada hewan yang diinduksi Oleum ricini, efeknya seperti loperamid. Loperamid mempengaruhi motilitas, frekuensi, konsistensi dan sekresi ${ }^{(14)}$.

\section{SIMPULAN}

Infusa daun senggani dosis $52 \mathrm{mg} / \mathrm{kg} \mathrm{BB}$ menunjukkan efek antidiare yang paling efektif dibandingkan dengan infusa daun senggani dosis $26 \mathrm{mg} / \mathrm{kg} \mathrm{BB}$ dan dosis $104 \mathrm{mg} / \mathrm{kg}$ BB pada mencit yang diinduksi Oleum ricini.

\section{DAFTAR PUSTAKA}

1. Kemenkes RI. Riset Kesehatan Dasar; RISKESDAS. Jakarta: Balitbang Kemenkes RI. 2013.

2. Kemenkes RI. Riset Kesehatan Dasar; RISKESDAS. Jakarta: Balitbang Kemenkes RI. 2018.

3. Purwanto, S. Uji aktivitas antibakteri fraksi aktif ekstrak etanol daun senggani (Melastoma malabathricum L) terhadap Escherichia Coli. Jurnal Ilmu Keperawatan Sriwijaya. 2015.2.

4. Hariana, A. 262 tumbuhan obat dan khasiatnya. Bogor: Penebar Swadaya; 2013.
5. Tangjitman, K., Wongsawad, C., Kamwong, K., Sukkho, T, dan Trisonthi, C. Ethnomedicinal plants used for digestive system disorders by the Karen of northern Thailand. Journal of Ethnobiology and Ethnomedicine. 2015. 11:27. DOI 10.1186/s13002015-0011-9

6. Silalahi, M., Nisyawati, dan Pandiangan, D. Medicinal plants used by the Batak Toba Tribe in Peadundung Village, North Sumatra, Indonesia. Biodiversitas. 2019. 20(2): 510-525. DOI: 10.13057/biodiv/d200230

7. Joffry, M. D., N. J. Yob, M. S. Rofiee, M. M. R. Meor Mohd. Affandi, Z. Suhaili, F. Othman, Md. Akim, M. N. M. Desa, and Z. A. Zakaria. Melastoma malabathricum (L.) Smith Ethnomedicinal Uses, Chemical Constituents, and Pharmacological Properties: A review. Evidence-Based Complementary and Alternative Medicine. 2012. 2012:48. doi:10.1155/2012/258434.

8. https://www.asiamedicinalplants.info/melastomamalabathricum-1/, diakses tanggal 10 September 2019.

9. M. Zakaria and M. A. Mohd, Traditional Malay Medicinal Plants, Fajar Bakti Sdn. Bhd., Kuala Lumpur, Malaysia. 1994.

10. Goodman \& Gilman. Dasar Farmakologi Terapi. Editor Joel G Hardman, Lee E. Limbird, Konsultan Editor Alfred Goodman Gilman. Alih bahasa Tim Alih Bahasa Sekolah Farmasi ITB. Edisi 10. Volume 1. Jakarta: EGC; 2007.

11. Departemen Kesehatan Republik Indonesia, Sediaan Galenik. Jakarta: Depkes RI; 1986.

12. Rahardja K dan Tjay, H T. Obat-Obat Penting. Jakarta: Elex Media Komputindo; 2007.

13. Nurhalimah, H., Wijayanti, N., Widyaningsih, T.D. Efek antidiare ekstrak daun beluntas (Pluchea indica 1.) terhadap mencit jantan yang diinduksi bakteri Salmonella thypimurium. Jurnal Pangan dan Agroindustri. 2015. 3(3): 1083-1094.

14. Sunilson J.A.J, Anandarajagopal K., Kumari, A, V, A, $\mathrm{G}$, dan Mohan, S. Indian journal of pharmaceutical sciences. 2009. 7(16): 691-695. 